\title{
Stylistic and typological features of students thinking as a factor of psychological readiness for innovative activity
}

\author{
Elena Suroedova ${ }^{1, *}$, Yulya Tushnova $^{1}$, Irina Bakaeva $^{2}$, and Elena Shevyreva ${ }^{2}$ \\ ${ }^{1}$ Don State Technical University, 1, Gagarin Square, Rostov-on-Don, 344003, Russia \\ ${ }^{2}$ Southern Federal University, 105/42, Bolshaya Sadovaya str., Rostov-on-Don, 344006, Russia
}

\begin{abstract}
This article discusses the quantitative characteristics of the features of the mental activity of students with different psychological readiness for innovation. The study involved 100 students of 2-4 bachelor's and 1-2 master's courses studying at the Faculty of "Agro-industrial" of DSTU, aged from 17 to 27 years $(\mathrm{M}=21.6, \mathrm{SD}=4.4$ (76.4\% men), studying at different levels of education (bachelor's degree - 66.8\% (M=19.8, $\mathrm{SD}=1.6,54.8 \%$ men $)$, master's degree $-34.2 \%(\mathrm{M}=22.6, \mathrm{SD}=3.5,53.5 \%$ men). The following methods were used: The questionnaire "Psychological readiness for innovation" (V. E. Klochko, O. M. Krasnoryadtseva); The method of measuring the style of thinking (A. K. Belousova); The questionnaire "Determining the type of thinking and the level of creativity" according to the method of J. Bruner; The questionnaire "Individual styles of thinking" (A. Alekseeva, L. Gromova); statistical methods. The study established the style and typological characteristics of students with different levels of psychological readiness for innovation, and also found that styles and types of thinking, as well as creativity affect the level of readiness for innovation. The prospects of the research are aimed at further studying the factors and predictors of readiness for innovation and developing recommendations for teachers to form universal competencies among students.
\end{abstract}

\section{Introduction}

The decisive transition of society to the innovative path of development objectively determines the need for psychological research of various aspects of innovation and training of competitive professionals in various sectors of the national economy. Today, the policy in the education system focuses on the formation of a new type of specialist who is ready and able to carry out innovative activities, be mobile in responding to and solving strategic problems of today, transform and master advanced domestic and foreign experience, knowledge, modern professional values, models and technologies, as well as all the qualities that would allow a future specialist to effectively carry out innovative activities in various professional fields. Practical approaches to the formation of psychological readiness for innovation professionals don't have uniformity, as well as there is no any developed

* Corresponding author: suroedova@mail.ru 
systematic approach, evidence-based solutions to important areas of formation of psychological readiness of students to innovate.

From the point of view of Russian scientists, innovation activity ensures the transformation of ideas into innovation, and also forms a system for managing this process. Innovation activity is characterized by consistency, integrality and integrity. It is defined as a set of measures taken to ensure the innovation process at a particular level, as well as the process itself [1].

V. E. Klochko E. V. Galazhinsky consider psychological readiness for innovative activity as a manifestation of the level of self-realization, primarily due to existing capabilities and a special type of system entities of axiological order determining the opening of the nature and form of psychological self-organizing systems in an innovative environment [2].

Foreign science highlights the weakness of innovative activity in agro-industrial complex. B. Corchuelo and F. J. Mesias, studying the barriers to innovation and improving the efficiency of firms, came to the conclusion that the most important element in the formation of competitiveness is the characteristics of companies as a whole, the risk-taking propensity and the manifestation of innovative activity. Scientists have identified the types, sorts and characteristics of companies and firms based on their willingness to innovate. Four types of agro-industries were identified in terms of their innovation policy and risk propensity [3]. Tuyaara Sidorova believes that the willingness to innovate is determined by the type of employee motivation. The author found that each type of motivation corresponds to a certain type of readiness for innovation [4]. Research by Charlyne Millet, David Oget \& Denis Cavallucci raises the issue of exploring creativity/innovation, efficiency/inefficiency for education policy development and improving engineering curricula. The authors study the inventive design process as one of the aspects of the innovation process [5]. Suroedova et al. studied the speech and communication competence of students of the agro-industrial complex [6]. As part of the readiness for innovation, it is peculiar that undergraduate students are distinguished by a higher accuracy of the transfer of essence and meanings of words, better interpretation of words.

A special role in the formation of psychological readiness for innovation, in our opinion, is played by stylistic and typological features of thinking. Especially if we consider thinking as a process of processing information from an influencing stimulus to solving a problem or achieving a goal [7]. Studies show that different styles of thinking do not equally affect a person's success in determining steps to meet needs, solving tasks, and overcoming difficulties. In addition, the stylistic and typological features of thinking are closely related to the motivation of the individual.

Chan, E., \& Unsworth, L. (2011) indicated that thinking styles are the preferred method of a person engaged in mental or practical activities [8]. According to Entwistle, thinking style refers to the definition of "cognitive style", used to distinguish between a variant and a tendency to think that is relatively stable between those with generally similar intellectual abilities.

Woolfolk's research revealed that different styles of thinking are used in solving problems, and the personality of the subject of activity is manifested. But the style of thinking does not reflect the level of intelligence or a particular ability. According to Kogan, Crowl, Kaminsky, and Podell, the style of thinking is connected with individual characteristics of attention, receiving and processing information, remembering and thinking. Moreover, Crowl, Kaminsky and Podell distinguish between the concept of thinking styles: "divergent thinking style" and "convergent thinking style". A divergent style of thinking is a pattern of human thinking that is more dominated by the functioning of the right hemisphere, whereas a convergent style of thinking is a way of thinking that is more dominated by the functioning of the left hemisphere [9]. 
According to A. Belousova, the style of thinking is one of the manifestations of the system regulation of thinking in the psychological system. Firstly, in the psychological system, the self-organization of thinking consists of adaptive processes related to solving existing problems and the goal to maintain the balance of the system. These processes ensure the stability of the system and its self-realization within the existing boundaries. Secondly, processes are aimed at the development of a system that goes beyond the actual boundaries of the system, as well as involve all sorts of changes due to conflicts, contradictions and changes within the system or the dynamics of its changes in the process of human life.

The objective level of these changes is associated with the development of formed neoplasms [10]. Thus, the style of thinking acts as a functional organization and a condition for the development of neoplasms in humans. In this regard, A. Belousova defines the style of thinking as a certain set of functions that are actualized by a person in various situations when solving problem situations and tasks. The study of thinking styles is most often associated with the learning process and professional activity. A number of foreign scientists' works show the importance of creative thinking and practical style of thinking activity in the educational activities of engineering students [11]. The critical style of thinking is less pronounced in students of technical and creative fields. Teachers are distinguished by a balanced style of thinking, where creative and critical styles are equally represented, which allows them to effectively solve professional problems, to show pedagogical competence in different forms of work with students [12].

In the work of Djadir, Hamzah Upu, four research subjects were correlated with different styles of thinking: sequential concrete, sequential abstract, random concrete, and random abstract. It was found that mathematical problem solving profiles influence students' choice of different strategies, as well as the quality and productivity of problem solving [13].

The results of the study by Ni Nyoman Sri Putu Verawati, Saiful Prayogi showed that the model of variable learning, which includes a reflexive process, is effective for the development of critical thinking in teachers with cognitive field-dependent and fieldindependent functions [14].

\section{Materials and methods}

The study involved 100 students of 2-4 bachelor's and 1-2 master's courses studying at the Faculty of "Agro-industrial" of DSTU, aged from 17 to 27 years $(\mathrm{M}=21.6, \mathrm{SD}=4.4$ (76.4\% men)), studying at different levels of education (bachelor's degree $-66.8 \%(\mathrm{M}=19.8, \mathrm{SD}=1.6$, $54.8 \%$ men)), master's degree $-34.2 \%(\mathrm{M}=22.6, \mathrm{SD}=3.5,53.5 \%$ men $)$ ). The following methods were used: 1) The questionnaire "Psychological readiness for innovation" (V. E. Klochko, O. M. Krasnoryadtseva); 2) The method of measuring the style of thinking (A. K. Belousova); 3) The questionnaire "Determining the type of thinking and the level of creativity" according to the method of J. Bruner; 4) The questionnaire "Individual styles of thinking" (A. Alekseeva, L. Gromova); statistical methods (descriptive statistics, Mann Whitney U test, multiple regression analysis (step-by-step)). Mathematical data processing was carried out using programs for analyzing statistical information.

The questionnaire forms were filled out by respondents with instructions to choose the most suitable answers for the respondent, reflecting the features of mental activity and the most preferred ways of solving problems.

The purpose of the research was to study the stylistic and typological features of students' thinking as factors of psychological readiness for innovation.

The tested assumptions were: 1) there might be differences in the features of thinking of students with different psychological readiness for innovation; 2) stylistic and typological features of thinking of students are predictors of psychological readiness for innovation. 


\section{Results}

In the course of the study, the sample was divided according to the levels of severity of signs of psychological readiness for innovation. The sample was divided according to the tables of standardization of the methodology. The assumption of differences in styles and types of thinking was tested using a pairwise comparison of the Mann Whitney U test groups (Tables 1-3). The tables show only statistically significant results.

Table 1. Styles and types of thinking of students with different levels of expression of the general indicator of psychological readiness for innovation.

\begin{tabular}{|c|c|c|c|c|c|c|}
\hline \multicolumn{2}{|c|}{$\begin{array}{c}\text { Group / Test } \\
\text { scale }\end{array}$} & $\begin{array}{c}\text { Critical STh } \\
\text { SThA }\end{array}$ & $\begin{array}{c}\text { Managerial } \\
\text { STh SThA }\end{array}$ & $\begin{array}{c}\text { Subject } \\
\text { thinking }\end{array}$ & $\begin{array}{c}\text { Sign } \\
\text { thinking }\end{array}$ & $\begin{array}{c}\text { Realistic } \\
\text { STh }\end{array}$ \\
\hline $\begin{array}{c}\text { Group } \\
1\end{array}$ & $\mathrm{n}=67$ & $\begin{array}{c}\mathrm{M}=22.7, \\
\sigma=3.1\end{array}$ & $\begin{array}{c}\mathrm{M}=22.8, \\
\sigma=3.5\end{array}$ & $\begin{array}{c}\mathrm{M}=8.7, \\
\sigma=2.5\end{array}$ & $\begin{array}{c}\mathrm{M}=8.8, \\
\sigma=3.2\end{array}$ & $\begin{array}{c}\mathrm{M}=56.0, \\
\sigma=7.7\end{array}$ \\
\hline $\begin{array}{c}\text { Group } \\
2\end{array}$ & $\mathrm{n}=31$ & $\begin{array}{c}\mathrm{M}=20.7, \\
\sigma=3.8\end{array}$ & $\begin{array}{c}\mathrm{M}=20.6, \\
\sigma=3.5\end{array}$ & $\begin{array}{c}\mathrm{M}=7.6, \\
\sigma=2.1\end{array}$ & $\begin{array}{c}\mathrm{M}=7.2, \\
\sigma=2.6\end{array}$ & $\begin{array}{c}\mathrm{M}=52.0, \\
\sigma=5.6\end{array}$ \\
\hline $\begin{array}{c}\text { Mann Whitney } \\
\text { U test }\end{array}$ & 743.0 & 717.5 & 775.0 & 738.0 & 676.0 \\
\hline \multicolumn{2}{|c|}{$\mathrm{p}$} & 0.023 & 0.014 & 0.042 & 0.021 & 0.006 \\
\hline
\end{tabular}

Notes: Group 1 - high level of expression of the general indicator of psychological readiness for innovation; Group 2 - average level of expression of the general indicator of psychological readiness for innovation; STh SThA - style of thinking in joint mental activity; STh - style of thinking.

It was found that the expression of thinking styles among students with a high and medium level of readiness for innovation activity is significantly different. The values of critical, managerial, realistic thinking styles and subject and sign thinking are significantly higher among students of the agro-industrial complex with a high level of readiness for innovation.

Further, the empirical group was divided according to the levels of severity of individual indicators of psychological readiness for innovation.

Table 2. Styles and types of thinking of students with different levels of expression of the indicator "Preference for activities that require innovation" psychological readiness for innovation.

\begin{tabular}{|c|c|c|c|c|c|c|}
\hline \multicolumn{2}{|c|}{$\begin{array}{c}\text { Group / Test } \\
\text { scale }\end{array}$} & $\begin{array}{c}\text { Initiative } \\
\text { STh SThA }\end{array}$ & $\begin{array}{c}\text { Critical } \\
\text { STh SThA }\end{array}$ & $\begin{array}{c}\text { Practical STh } \\
\text { SThA }\end{array}$ & $\begin{array}{c}\text { Creativ } \\
\text { ity }\end{array}$ & $\begin{array}{c}\text { Synthetic } \\
\text { STh }\end{array}$ \\
\hline $\begin{array}{c}\text { Group } \\
3\end{array}$ & $\mathrm{n}=57$ & $\begin{array}{c}\mathrm{M}=20.0, \\
\sigma=2.0\end{array}$ & $\begin{array}{c}\mathrm{M}=22.0, \\
\sigma=3.2\end{array}$ & $\mathrm{M}=22.8, \sigma=3.1$ & $\begin{array}{c}\mathrm{M}=9.6, \\
\sigma=2.1\end{array}$ & $\begin{array}{c}\mathrm{M}=51.8, \\
\sigma=6.6\end{array}$ \\
\hline $\begin{array}{c}\text { Group } \\
4\end{array}$ & $\mathrm{n}=38$ & $\begin{array}{c}\mathrm{M}=20.0, \\
\sigma=2.3\end{array}$ & $\begin{array}{c}\mathrm{M}=21.1, \\
\sigma=3.6\end{array}$ & $\mathrm{M}=22.1, \sigma=2.6$ & $\begin{array}{c}\mathrm{M}=8.0, \\
\sigma=1.9\end{array}$ & $\begin{array}{c}\mathrm{M}=51.9, \\
\sigma=5.8\end{array}$ \\
\hline $\begin{array}{c}\text { Group } \\
5\end{array}$ & $\mathrm{n}=5$ & $\begin{array}{c}\mathrm{M}=22.0, \\
\sigma=2.4\end{array}$ & $\begin{array}{c}\mathrm{M}=23.2, \\
\sigma=3.1\end{array}$ & $\mathrm{M}=25.8, \sigma=1.6$ & $\begin{array}{c}\mathrm{M}=8.6, \\
\sigma=3.3\end{array}$ & $\begin{array}{c}\mathrm{M}=57.6, \\
\sigma=3.2\end{array}$ \\
\hline \multicolumn{2}{|c|}{} & Group 3-5 & Group 3-4 & $\begin{array}{c}\text { Group 3-5 } \\
\text { Group 4-5 }\end{array}$ & $\begin{array}{c}\text { Group } \\
3-4\end{array}$ & $\begin{array}{c}\text { Group 3 -5 } \\
\text { Group 4-5 }\end{array}$ \\
\hline $\begin{array}{c}\text { Mann Whitney } \\
\text { U test }\end{array}$ & 69.5 & 793.0 & $\begin{array}{c}63.0 \\
21.5\end{array}$ & 640.5 & $\begin{array}{c}59.5 \\
40.0\end{array}$ \\
\hline \multicolumn{2}{|c|}{$\mathrm{p}$} & 0.05 & 0.027 & $\begin{array}{c}0.038 \\
0.003\end{array}$ & 0.001 & $\begin{array}{c}0.029 \\
0.036\end{array}$ \\
\hline
\end{tabular}

Notes: Group 3 - high level of severity of the overall indicator "A preference for activities that require innovation"; Group 4 - the average level of severity of the general indicator of "Preference for activities that require innovation"; Group 5 - low level of expression of a common measure of "Preference to activities that require innovativeness»; STh SThA - style of thinking in joint mental activity; STh - style of thinking.

It is established that there are differences in the expression of thinking styles and creativity between students with different levels in the indicator "Preference for activities that 
require innovation". Students with a high level of preference for activities that require innovation, reliably expressed critical thinking style and creativity. Students with a low level of preference for activities that require innovation have significantly expressed initiative, practical and synthetic thinking styles.

Table 3. Styles and types of thinking of students with different levels of expression of the indicator "Readiness for change" of psychological readiness for innovation.

\begin{tabular}{|c|c|c|c|c|c|c|}
\hline \multicolumn{2}{|c|}{$\begin{array}{c}\text { Group / Test } \\
\text { scale }\end{array}$} & $\begin{array}{c}\text { Initiative } \\
\text { STh SThA }\end{array}$ & $\begin{array}{c}\text { Critical } \\
\text { STh SThA }\end{array}$ & $\begin{array}{c}\text { Managerial } \\
\text { STh SThA }\end{array}$ & $\begin{array}{c}\text { Iconic } \\
\text { thinking }\end{array}$ & Creativity \\
\hline $\begin{array}{c}\text { Group } \\
6\end{array}$ & $\mathrm{n}=66$ & $\begin{array}{c}\mathrm{M}=20.4, \\
\sigma=2.2\end{array}$ & $\begin{array}{c}\mathrm{M}=22.9, \\
\sigma=3.3\end{array}$ & $\begin{array}{c}\mathrm{M}=23.0 .7, \\
\sigma=3.3\end{array}$ & $\begin{array}{c}\mathrm{M}=8.9, \\
\sigma=3.1\end{array}$ & $\begin{array}{c}\mathrm{M}=9.3, \\
\sigma=2.2\end{array}$ \\
\hline $\begin{array}{c}\text { Group } \\
7\end{array}$ & $\mathrm{n}=30$ & $\begin{array}{c}\mathrm{M}=19.3, \\
\sigma=2.1\end{array}$ & $\begin{array}{c}\mathrm{M}=20.8, \\
\sigma=3.4\end{array}$ & $\begin{array}{c}\mathrm{M}=20.6, \\
\sigma=3.7\end{array}$ & $\begin{array}{c}\mathrm{M}=7.1, \\
\sigma=2.6\end{array}$ & $\begin{array}{c}\mathrm{M}=8.2, \\
\sigma=2.0\end{array}$ \\
\hline $\begin{array}{c}\text { Mann Whitney } \\
\text { U test }\end{array}$ & 696.5 & 692.5 & 837.5 & 682.5 & 671.5 \\
\hline \multicolumn{2}{|c|}{$\mathrm{p}$} & 0.019 & 0.018 & 0.004 & 0.015 & 0.011 \\
\hline
\end{tabular}

Notes: Group 6 - high level of expression of the indicator "Readiness for change"; Group 7 - medium level of expression of the indicator "Readiness for change»; STh SThA - style of thinking in joint mental activity.

The stylistic and typological features of students' thinking with different levels of readiness for change were revealed. Initiative, critical, managerial thinking styles, sign thinking, and creativity are significantly higher in students with a high level of readiness for change than in those with an average level.

The results of the study of styles and types of thinking as predictors of students' psychological readiness for innovation allow us to establish several models. The results of the multiple regression analysis are presented in Tables 4-6.

Table 4. Model of styles and types of thinking as predictors of psychological readiness for innovation. Overall indicator.

\begin{tabular}{|c|c|c|c|c|c|c|}
\hline \multirow{2}{*}{$\begin{array}{c}\text { Styles and types of } \\
\text { thinking }\end{array}$} & $\begin{array}{c}\text { Model } \\
\text { Summary }\end{array}$ & \multicolumn{2}{|c|}{ ANOVAa } & $\begin{array}{c}\text { Standardized } \\
\text { Coefficients }\end{array}$ & \multirow{2}{*}{ t } & sig \\
\cline { 2 - 5 } & R Square & F & sig & Beta & & \\
\hline Creativity & 0.124 & 6.870 & 0.002 & 0.299 & 3.111 & 0.002 \\
\hline Realistic STh & & & 0.237 & 2.461 & 0.016 \\
\hline
\end{tabular}

Notes: STh SThA - style of thinking in joint mental activity ; STh - style of thinking.

The results of the analysis showed that realistic thinking style and creativity are significant predictors of psychological readiness for innovation.

Table 5. Model of styles and types of thinking as predictors of psychological readiness for innovation activity according to the indicator "Preference for activities that require innovation».

\begin{tabular}{|c|c|c|c|c|c|c|}
\hline \multirow{2}{*}{$\begin{array}{c}\text { Styles and types of } \\
\text { thinking }\end{array}$} & \multirow{2}{*}{$\begin{array}{c}\begin{array}{c}\text { Model } \\
\text { Summary }\end{array} \\
\text { R Square }\end{array}$} & \multicolumn{2}{|c|}{ ANOVAa } & $\begin{array}{l}\text { Standardized } \\
\text { Coefficients }\end{array}$ & \multirow{2}{*}{ t } & \multirow{2}{*}{ sig } \\
\hline & & $\mathbf{F}$ & ig & Beta & & \\
\hline Initiative STh SThA & \multirow{4}{*}{0.243} & \multirow{4}{*}{7.623} & \multirow{4}{*}{0.000} & -0.240 & -2.677 & 0.009 \\
\hline Creativity & & & & 0.347 & 3.837 & 0.000 \\
\hline Idealistic STh & & & & 0.195 & 2.151 & 0.034 \\
\hline Realistic STh & & & & 0.276 & 2.995 & 0.003 \\
\hline
\end{tabular}

Notes: STh SThA - style of thinking in joint mental activity; STh - style of thinking.

Thinking styles of initiative, idealistic, realistic, and creativity influence the preference for activities that require innovation. 
Table 6. Model of styles and types of thinking as predictors of psychological readiness for innovation activity according to the indicator "Readiness for change»

\begin{tabular}{|c|c|c|c|c|c|c|}
\hline $\begin{array}{c}\text { Styles and types of } \\
\text { thinking }\end{array}$ & $\begin{array}{c}\text { Model } \\
\text { Summary }\end{array}$ & \multicolumn{2}{|c|}{ ANOVAa } & $\begin{array}{c}\text { Standardized } \\
\text { Coefficients }\end{array}$ & \multirow{2}{*}{ t } & sig \\
\cline { 2 - 5 } & R Square & F & sig & Beta & & \\
\hline Creativity & 0.040 & 4.059 & 0.047 & 0.199 & 2.015 & 0.047 \\
\hline
\end{tabular}

A possible trend of the influence of creativity on the readiness for change in students is revealed.

\section{Discussion of the results}

The analysis of the obtained results shows that more than half of the students participating in the study have a fairly high degree of psychological readiness for innovation (above average level). This category of respondents is characterized by openness to the world and to themselves, an internal locus of control, developed flexibility, expressed willingness to act in conditions of uncertainty, self-confidence and responsibility for the results of their activities; they have sufficiently formed preferences in the choice of areas of self-realization associated with the generation of innovative forms of behavior and activity. Almost 1/3 of the respondents have an average level of expression of indicators of psychological readiness for innovation. A low level of the studied signs is quite rare, characterizing no more than $2 \%$ of students.

Students with a high level of psychological readiness for innovation are characterized by a greater expression of critical, managerial, realistic thinking styles and types of thinking such as subject and sign. This means that students with a formed preference in choosing areas of self-realization associated with the generation of innovative forms of behavior and activity are more dominated by the selective function, evaluation and selection of information; they are dominated by the function of meaning transmission, the focus on the organization of other people; they are more specific and set on checking and correcting the situation in order to achieve a certain result. Students with a high level of psychological readiness for innovation are characterized by a greater degree of practical and humanitarian mindset.

Students with a formed preference for such areas of activity and self-realization that do not require updating the existing behavioral and activity stereotypes are distinguished by the dominance in joint mental activity of the function of generation, search for contradictions, detection of problems, hypotheses; in addition, they dominate more than in the other two groups, in the function of implementation, the desire for practical implementation of ideas, hypotheses; students with a low expression of the indicator are more sensitive to contradictions in the reasoning of others, show an increased interest in paradoxes and conflicts of ideas. Students with a high level of preference for activities that require innovation are characterized by a pronounced predominance of selective function, evaluation and selection of information than students with an average level. Creativity is more evident in students with a high level of the indicator "Preference for activities that require innovation".

The results of the study of the style and typological features of the thinking of students with different levels of readiness for change showed that the students with a high level of this indicator have higher values for initiative, critical and managerial thinking styles, sign type of thinking and creativity. These data allow us to say that young people with such characteristics as a person's openness to himself and the world, developed flexibility, internal locus of control, self-confidence are characterized by greater dynamics of developing different ideas, sensitivity to different problems, hypotheses; more pronounced dominance of the selective function, or the selection and evaluation of information; a predominance of 
functions of meaning transfer (in the subject area, the material of the specific tasks of the meanings transmission of new knowledge) as well as meaning transfer aimed at other people connected with a sense of activity and its values. In addition, students with a high level of Furthermore readiness for change is distinguished by a humanitarian mindset, the ability to transform information with the help of inferences, more developed creative abilities, characterized by a willingness to create fundamentally new ideas.

The study of stylistic and typological features as predictors of psychological readiness for innovation activity showed that creativity plays the greatest role. This is noted both in the general indicator and in the indicators of psychological readiness for innovation (except for the indicator of initiative). Psychological readiness for innovation is determined by a realistic style of thinking and creativity. The preference for activities that require innovation is determined by creativity, realistic, proactive and idealistic thinking styles. Peculiar, the indicator of the initiative style of thinking has negative coefficients; according to the equation, the ability to develop different ideas, sensitivity to different problems, hypothesizing, theoretical thinking negatively affect the openness of the individual, responsibility, flexibility.

The data obtained correlate with the results of studies by E. Revilla and B. RodriguezPrado, which found that creativity increases the propensity for innovation [15]. Hessamoddin Sarooghib, Dirk Libaersa, and Andrew Burkemper found a strong positive relationship between creativity and innovation, especially at the individual level [16].

\section{Conclusions}

The results of the study of stylistic and typological features of students' thinking as factors of psychological readiness for innovation activity allowed us to draw the following conclusions.

The majority of students who took part in the study have a fairly high degree of psychological readiness for innovation (above average level). Students with a high level of psychological readiness differ from students with an average level in more pronounced thinking styles: critical, managerial, realistic, and types of subject and sign thinking. Students with a low level of formation of preferences for activities that require an innovative approach and novelty are characterized by a greater expression of thinking styles: initiative, practical, synthetic. Students with a high level of readiness for change showed higher indicators, in contrast to respondents with an average level, in the styles of thinking initiative, critical, managerial, in the type of sign thinking and creativity.

It is established that creativity has the greatest positive impact on the formation of psychological readiness for innovation. Idealistic and realistic thinking styles also have a positive effect on psychological readiness for innovation. The initiative style of joint thinking activity has a negative impact on the openness of the individual, responsibility, flexibility, that is, on the preference for activities that require innovation.

The prospects of the research are aimed at further studying the factors and predictors of readiness for innovation and developing recommendations for teachers to form universal competencies among students.

\section{References}

1. O.M. Krasnorjadtseva, D.U. Balanev, E.A. Sheglova, Siberian Journal Of Psychology 40, 164-175 (2011) http://journals.tsu.ru/uploads/import/989/files/164-175.pdf

2. V.E. Klochko, Siberian Journal Of Psychology 40, 136-151 (2011) http://vital.lib.tsu.ru/vital/access/manager/Repository/vtls:000494815 
3. B. Corchuelo, F.J. Mesias, Itea-Informacion Tecnica Economica Agraria 113, 176-191 (2017) 10.12706/itea.2017.011

4. T. Sidorova, Psychology And Psychiatry, Sociology And Healthcare, Education I, 471475 (2014) https://apps.webofknowledge.com/full_record.do?product=WOS \&search_mode $=$ GeneralSearch\&qid $=6 \& S I D=D 3 B V P Z T K 82$ UoB3yWAqq\&page $=1 \&$ $\mathrm{doc}=4$

5. Ch. Millet, D. Oget, D. Cavallucci, European Journal of Engineering Education 42(6), 1000-1024 (2017) DOI: 10.1080/03043797.2016.1249341

6. E. Suroedova, Y. Tushnova, E. Belousova, E3S Web of Conferences 175, 15028 (2020) https://doi.org/10.1051/e3sconf/202017515028

7. A. Sander, Thinking Style in Learning: Gaya Berpikir dalam Menentukan Prinsipprinsip dalam Belajar (2011) http://ahsansander.blogspot.com/1011/09/thingkingstyle-inlearning.html

8. E. Chan, L. Unsworth, The Australian Educational Researcher 38(2), 181-202 (2011) DOI: $10.1007 / \mathrm{s} 13384-011-0023-y$

9. J. Patahuddin, Phys.: Conf. Ser. 1028, 012097 (2018) doi :10.1088/17426596/1028/1/012097

10. A. Belousova, Y. Mochalova, Behav. Sci. 10, 68 (2020) doi:10.3390/bs10030068 http://creativecommons.org/licenses/by/4.0/

11. J. Huincahue, C. Gaete-Peralta, V. Garrido Véliz, International Journal of Cognitive Research in Science, Engineering and Education (IJCRSEE) 7(1), 21-33 (2019) doi:10.5937/ijcrsee1901021H

12. Shanty Saien, Tee Tze Kiong, Jailani Md Yunos et al., Journal Of Technical Education And Training 11(3), 043-048 (2019) https://doi.org/10.30880/jtet.2019.11.03.006

13. Djadir Hamzah Upu, A. Sulfianti Journal of Physics: Conf. Series 1028, 012164 (2018) doi :10.1088/1742-6596/1028/1/012164

14. Ni Nyoman Sri Putu Verawati, H. Hikmawati, S. Prayogi, International Journal of Emerging Technologies in Learning (iJET) 16(03), 212-2020 (2021) https://doi.org/10.3991/ijet.v15i16.14687\%0d

15. E. Revilla, B. Rodriguez-Prado, RESEARCH POLICY 47(99), 1611-1625 (2018) 10.1016/j.respol. 2018.05.009

16. H. Sarooghi, D. Libaers, A. Burkemper, Journal of Business Venturing 30(5), 714-731 (2015) https://doi.org/10.1016/j.jbusvent.2014.12.003 